\title{
IDENTIFIKASI KONDISI TERUMBU KARANG PERAIRAN BAGIAN SELATAN PULAU SEPANJANG, KABUPATEN SUMENEP DENGAN MENGGUNAKAN CITRA LANDSAT 8
}

\author{
Ilham B Mataburu \\ Dosen Jurusan Geografi FIS UNJ \\ E-mail: ilham.bm93@gmail.com
}

\begin{abstract}
ABSTRAK
Penelitian ini bertujuan untuk mengenai bagaimana sebaran dan kondisi terumbu karang dengan mengunakan citra landsat 8. Lokasi peneltian dilakukan di perairan sekitar Pulau Sepanjang, Kecamatan Sapeken Kabupaten Sumenep. Penelitian ini mengunakan metode deskriptif kuantitatif dengan menggunakan persamaan Lyzenga dan diterapkan pada Citra Landsat 8 dan dilakukan verifikasi lapangan. Hasil penelitian menunjukan bahwa perbedaan antara hasil pengamatan lapangan dengan hasil analisis mencapai 37,5\% perbedaan ini dijadikan sebagai dasar untuk melakukan koreksi pada citra untuk menghasilkan citra yang lebih tepat. Dan secara umum penggunaan persamaan/algoritma lyzenga pada landsat 8 bisa digunakan untuk mendeteksi kondisi umum terumbu karang khususnya untuk mendeteksi terumbu karang hidup dan mati, sebagai langkah awal untuk mengidentifikasi kualitas terumbu karang.
\end{abstract}

Kata Kunci : Terumbu karang, Lyzenga, Citra Landsat 8

\section{PENDAHULUAN}

Indonesia merupakan Negara kepulauan terbesar di dunia. Luas perairan Indonesia meliputi 2/3 luas wilayah Negara Republik Indonesia. Perairan Indonesia begitu kaya dengan berbagai biota perairan yang bias dijadikan sebagai sumber devisa bagi Negara. Eksploitasi sumberdaya perairan laut yang tidak tepat menyebabkan terjadinya kemunduran kualitas lingkungan perairan yang juga membahayakan kelangsungan hidup biota perairan. Termasuk diantara keberadaan terumbu karang yang rentan atas berbagai gangguan. Sebagaimana diketahui bahwa keberadaan terumbu karang memiliki arti penting bagi kelangsungan berbagai jenis ikan. Berbagai jenis ikan menjadikan terumbu karang sebagai tempat memijah serta mencari makanan, bias dikatakan secara langsung bahwa terumbu karang menjadi indicator penting keberlangsungan sumberdaya perairan.

Selain sebagai salah satu penentu kritis keberlangsungan sumberdaya perairan, Ekosistem terumbu karang juga merupakan ekosistem yang rentan terhadap gangguan. Sedikit saja gangguan akan berdampak pada keberlangsungan ekosistem ini. Kegiatan penangkapan ikan dengan cara yang tidak tepat seperti penggunaan racun ikan, penggunaan bom, jaring yang merusak serta penambangan karang akan mempercepat rusaknya terumbu karang. Oleh karena pemanfaatan dan pengelolaan sumberdaya perairan yang memperhatikan prinsipprinsip keberlangsungan sumberdaya terumbu karang mutlak diperlukan.

Dengan potensi keanekaeagaman hayati laut tertinggi, Indonesia memiliki 2,500 spesies molluska, 2,000 spesies krustasea, 6 spesies penyu laut, 30 mamalia laut, dan lebih dari 2,500 spesies ikan laut. Luas ekosistem terumbu karang Indonesia diperkirakan mencapai $75.000 \mathrm{~km} 2$ yaitu sekitar 12 sampai 15 persen dari luas terumbu karang dunia. Dengan ditemukannya 362 spesies scleractinia (karang batu) yang termasuk dalam 76 genera, Indonesia merupakan episenter dari sebaran karang batu dunia. Ekosistem pesisir (padang lamun, mangrove dan terumbu karang) memainkan peranan penting dalam industri wisata bahari, selain memberikan pelindungan pada kawasan pesisir dari hempasan ombak dan gerusan arus. Selain itu ekossistem pesisir ini merupakan tempat bertelur, membesar dan mencari makan dari beaneka ragam biota laut 
yang kesemuanya merupakan sumber produksi penting bagi masyarakat pesisir. Lembaga IImu Pengetahuan Indonesia (LIPI) mencatat, hampir sepertiga kondisi terumbu karang di Indonesia mengalami kerusakan atau kurang baik. Meskipun kondisi ini telah mengalami tren membaik dalam sepuluh tahun terakhir. Survei terbaru dilakukan oleh LIPI. Dengan melakukan pengamatan di 1.135 stasiun, hingga 2013, tercatat 5,29 persen dalam kondisi sangat baik, sebesar 27,14 persen masih dalam kondisi baik, dan sebesar 37,18 persen dalam kondisi cukup. Sisanya sebesar 30,4 persen dalam kondisi tidak baik.

Ekosistem terumbu karang adalah ekosistem yang mengandung sumber daya alam yang dapat memberi manfaat besar bagi manusia. Dari itu diperlukan kearifan manusia untuk mengelolanya, yang bisa menjadikan sumber daya alam ini menjamin kesejahteraan manusia sepanjang zaman. Tanpa menghiraukan masa depan dan terus-menerus merusak, ekosistem terumbu karang akan menjadi semacam padang gurun tandus di dalam laut yang hanya dipenuhi oleh patahan-patahan karang dan benda mati lainnya. Karena itu pengelolaan sangat diperlukan untuk mengatur aktivitas manusia serta mengurangi dan memantau cara-cara pemanfaatan yang merusak. Pengelolaan terumbu karang harus berbasis pada keterlibatan masyarakat, sebagai pengguna langsung sumber daya laut ini. Keterlibatan masyarakat dalam pengelolaan sumber daya terumbu karang sangat penting mulai dalam tahap perencanaan, pelaksanaan, pemantauan sampai pada tahap evaluasi dari suatu cara pengeloaan. Indonesia yang terletak di sepanjang katulistiwa, mempunyai terumbu karang terluas di dunia tersebar mulai dari Aceh sampai Irian Jaya. Dengan jumlah penduduk 200 juta jiwa, yang 60 persennya tinggal di daerah pesisir, maka terumbu karang merupakan tumpuan sumber penghudupan utama. Salah satu wilayah yang memiliki terumbu karang yang cukup beragam adalah wilayah perairan sekitar Pulau Sepanjang di wilayah Kepulauan Sapeken, yang merupakan wilayah administrative Kabupaten Sumenep Provinsi Jawa Timur. Posisi pulau Sepanjang berada persis sebelah utara Pulau Bali.

Identifikasi sebaran dan kualitas terumbu karang yang cepat dan murah mutlak diperlukan untuk memantau perkembangan kualitas lingkungan terumbu karang secara cepat dan efisien. Penggunaan citra satelit bisa dijadikan sebagai salah satu alternative untuk hal tersebut. Salah satu yang bisa dijadikan sebagai referensi adalah Landsat 8 . Landsat 8 merupakan kelanjutan dari misi Landsat yang untuk pertama kali menjadi satelit pengamat bumi sejak 1972 (Landsat 1). Landsat 1 yang awalnya bernama Earth Resources Technology Satellite 1 diluncurkan 23 Juli 1972 dan mulai beroperasi sampai 6 Januari 1978. Generasi penerusnya, Landsat 2 diluncurkan 22 Januari 1975 yang beroperasi sampai 22 Januari 1981. Landsat 3 diluncurkan 5 Maret 1978 berakhir 31 Maret 1983; Landsat 4 diluncurkan 16 Juli 1982, dihentikan 1993. Landsat 5 diluncurkan 1 Maret 1984 masih berfungsi sampai dengan saat ini namun mengalami gangguan berat sejak November 2011, akibat gangguan ini, pada tanggal 26 Desember 2012, USGS mengumumkan bahwa Landsat 5 akan dinonaktifkan. Berbeda dengan 5 generasi pendahulunya, Landsat 6 yang telah diluncurkan 5 Oktober 1993 gagal mencapai orbit. Sementara Landsat 7 yang diluncurkan April 15 Desember 1999, masih berfungsi walau mengalami kerusakan sejak Mei 2003.

Aplikasi landsat 8 belum banyak dilakukan terutama dalam bidang kelautan. Berdasarkan keadaan tersebut penelitian ini dilakukan untuk menerapkan penggunaan Landsat 8 dalam mengidentifikasi terumbu karang. Wilayah yang dijadikan sebagai tempat penelitian adalah perairan sebelah selatan Pulau Sepanjang di Kecamatan Sapeken, Kabupaten Sumenep.

Masalah penelitian yang diajukan dalam penelitian ini adalah:

1.Bagaimana penggunaan Citra Landsat 8 dalam menentukan sebaran terumbu karang di wilayah perairan Pulau Sapeken Kabupaten Sumenep 
2.Bagaimana penerapan Citra Landsat 8 dalam menentukan kondisi Terumbu Karang di wilayah perairan Pulan Sapaken
METODOLOGI PENELITIAN

Metode penelitian dilakukan secara deskriptif kuantitatif dengan menganalisis citra landsat 8 berdasarkan persamaan lyzenga. Secara skematis, metode penelitian dilakukan sebagai berikut:

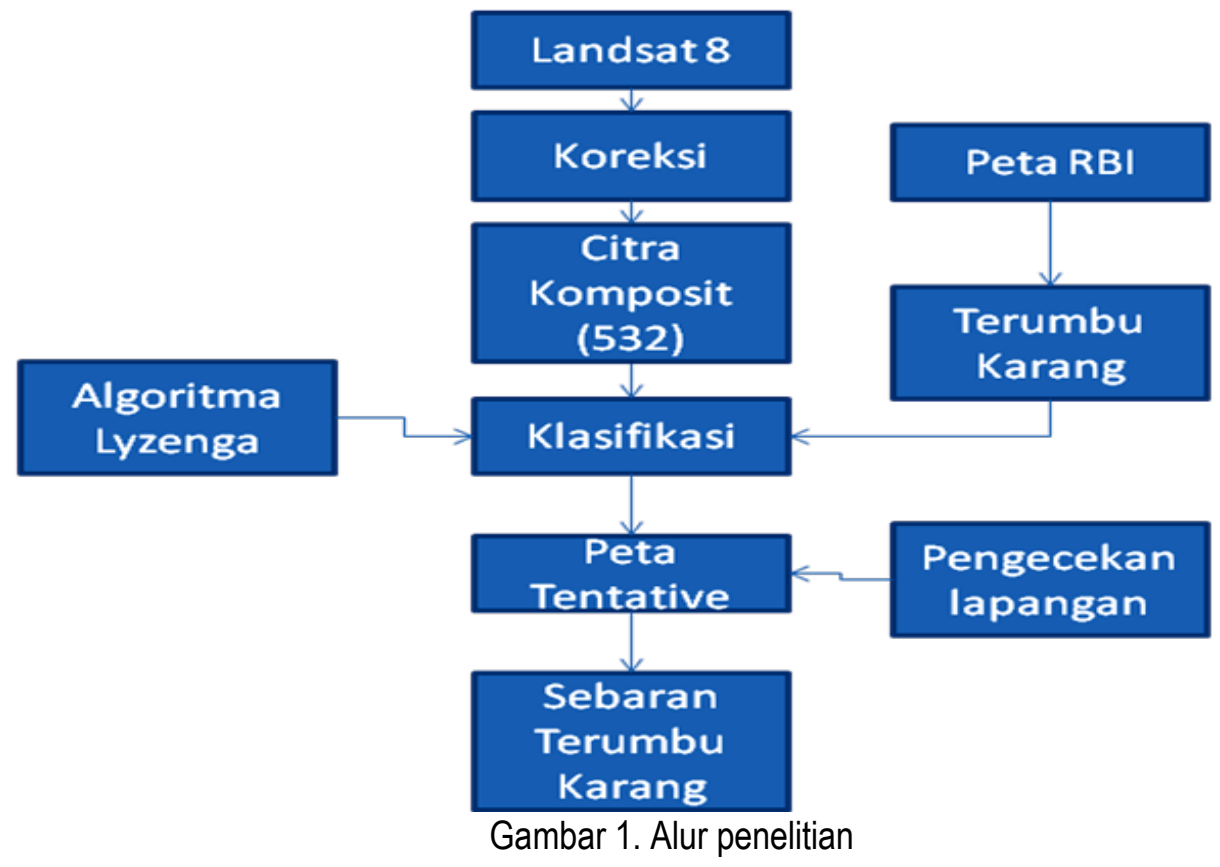

Penelitian ini menggunakan beberapa data primer dan sekunder antara lain :

1.Data primer (data penginderaan jauh): Landsat 8 lembar Pulau Sapeken Path/Row 117/065 perekaman tanggal 03 September 2014.

2.Data sekunder: Peta Rupa Bumi Indonesia 1:25.000 lembar Pulau Sapeken tahun 2000

Adapun perangkat yang digunakan dalam pengolahan data dalam penelitian ini adalah Software ER Mapper ver 8.0, Software Arc GIS 10.1, serta piranti Microsoft Office Excel dan Office 2010. Citra Landsat ETM+ yang digunakan adalah citra Landsat 7 ETM+ tanggal 28 Juni 1997 dan 4 Mei 2009 dan citra Landsat 5 TM tanggal 9 September 2006. Pengolahan citra dilakukan dengan menggunakan formula lyzenga. Pengolahan citra dilakukan untuk melihat sebaran terumbu karang yang terdapat pada wilayah Kepulauan Karimunjawa. Adapun proses pengolahan pada citra adalah sebagai berikut:

1.Menampilkan citra Landsat dalam bentuk Red Green Blue (RGB) dengan band 532 untuk analisis presentase keberadaan karang hidup. Masing-masing band tersebut digunakan untuk:

a.Band 5 digunakan untuk penentuan materi biomas dan delineasi tumbuhan air.

b. Band 3 digunakan untuk mengetahui tingkat kesuburan vegetasi.

c. Band 2 digunakan untuk mengetahui tingkat kekeruhan air.

2.Melakukan koreksi geometrik dan radiometrik (penajaman citra)

a. Koreksi Radiometrik

b. Koreksi Geometrik

3.Mengekstrak informasi kelautan (terumbu karang) dengan formula Lyzenga. Pengolahan citra Landsat ETM+ untuk pemetaan terumbu karang dilakukan dengan menggunakan metode 
Lyzenga. Pada metode ini pendekatan algoritma dilakukan dengan menggunakan koefisien attenuasi data Landsat ETM+ band 1 dan band 2 untuk dikombinasikan secara logaritma natural sehingga dihasilkan band baru. Persamaan Lyzenga ini kemudian dikembangkan berdasarkan Exponential Attenuation Model.

$Y=\ln (T M 1)+k i / k j \ln (T M 2)$

Dimana :

$Y=$ citra hasil ekstrasi dasar perairan

TM1 = nilai digital kanal 1 Landsat TM

TM2 = nilai digital kanal 2 Landsat TM

$\mathrm{ki} / \mathrm{kj}=$ nilai koefisien atenuasi

dimana,

$\mathrm{ki} / \mathrm{kj}=\mathrm{a}+{ }^{2}+1$

dengan,

$\mathrm{a}=(\operatorname{var}$ TM1 - var TM2) / (2 + covar TM1TM2)

var = nilai ragam dari nilai digital

covar $=$ nilai koefisien keragaman dari nilai digital
Untuk mendapatkan nilai ki dan kj dilakukan pengukuran nilai-nilai digital langsung pada monitor secara interaksi langsung pada kedua kanal dan perolehan varian dan kovarian. Formula untuk menghilangkan efek perairan dan daratan adalah:

if i1<=DN then $\log (i 2)+\left(k^{\prime} / k^{*} \log (i 3)\right.$ else null dimana:

$\mathrm{i} 1=$ Band 5

i2 $=$ Band 2

i3 $=$ Band 3

DN adalah batas nilai perairan dan daratan pada kanal 3 di daerah penelitian.

4.Melakukan masking area untuk menghilangkan tutupan awan dan perairan.

If i1 $>=D N$ then i1 else null

$\mathrm{DN}$ adalah batas nilai digital number laut serta awan

5.Melakukan klasifikasi citra secara tak terbimbing untuk menentukan daerah terumbu karang, daratan, lamun dan pasir.

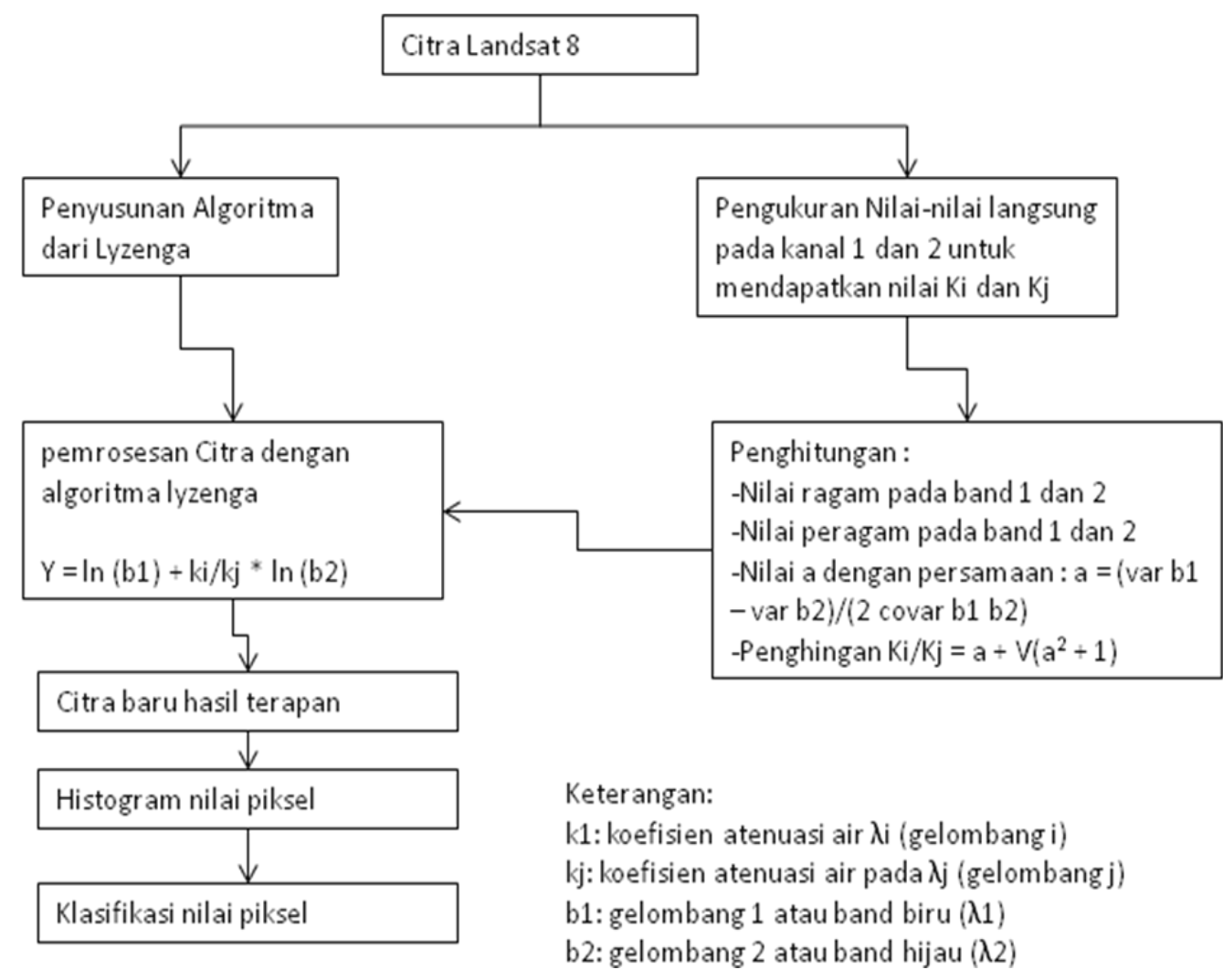

Gambar 2. Prosedur Lyzenga (Wening, 2005) 


\section{HASIL DAN PEMBAHASAN}

\section{Kondisi Umum}

Pulau Sepanjang termasuk kedalam Kecamatan Sapeken, Kabupaten Sumenep Provinsi Jawa Timur. Wilayah perairan Kepulaun Sepanjang dan sekitarnya sebagai Kawasan Konservasi Laut Daerah seluas \pm 118.406 .2 hektar. Dasar hukum penetapan Kawasan Konservasi Laut Daerah (KKLD) Kabupaten Sumenep adalah SK Bupati No. 8 Tahun 2010 yang dikeluarkan pada tanggal 3 Mei 2010. Pemanfaatan Kawasan Konservasi Laut Daerah Kabupaten Sumenep diprioritaskan untuk melindungi potensi perikanan dan kelautan secara berkelanjutan demi peningkatan kesejahteraan masyarakat, budidaya yang ramah lingkungan dan wisata bahari.

Pulau Sepanjang terletak di bagian Timur gugusan kepulauan Kangean dengan posisi disisi utara Pulau Bali termasuk dalam wilayah Kecamatan Sapeken, Kabupaten Sumenep Propinsi Jawa Timur. Pulau Sepanjang memiliki luas wilayah 103.4. $\mathrm{km}^{2}$ (10340 Ha), terdiri atas dua desa yakni desa Tanjung Kiaok dan desa Sepanjang. Secara geografis Pulau Sepanjang terletak pada posisi $07^{0} 6^{\prime}$ 07.1" - Lintang Selatan dan $115^{\circ}$ 59' 17.2" - Bujur Timur, dan berada pada ketinggian maximum $13 \mathrm{~m}$ di atas permukaan air laut.

Pulau Sepanjang yang merupakan bagian Gugus Pulau Kangean dikelilingi oleh perairan, dimana disebelah Barat dan Utara berbatasan dengan Laut Jawa, sebelah Timur dan Selatan berbatasan dengan Laut Bali. Secara umum dapat dikatakan bahwa perairan laut yang mengelilingi Gugus Pulau Kangean di sebelah Utara dan barat adalah perairan yang dangkal dengan kedalaman laut sampai dengan batas 4 mil berkisar antara 2 $70 \mathrm{~km}$. Sedangkan perairan sebelah Timur dan Selatan merupakan perairan dalam, dimana kedalaman laut sampai batas 4 mil berkisar antara 2-190 meter.

Kecepatan arus di sekitar Pulau Sepanjang di permukaan berkisar antara $0.56-0.95 \mathrm{~m} / \mathrm{s}$ sedang arus di dasar laut berkisar antara $0.29-0.42 \mathrm{~m} / \mathrm{s}$. Tinggi gelombang laut sangat tergantung pada kondis cuaca dan musim yang terjadi. Distribusi tinggi gelombang aut disekitar Pulau Sepanjang rata-rata berkisar antara $0.5-3.4 \mathrm{~m}$. Suhu air berkisar antara $28,2{ }^{\circ} \mathrm{C}$ di permukaan hingga 21,6 ${ }^{\circ} \mathrm{C}$ pada kedalaman sekitar $100 \mathrm{~m}$. Sedang suhu udara berkisar antara $20^{\circ} \mathrm{C}-34^{\circ} \mathrm{C}$.

Perbandingan hasil pengamatan lapangan dengan hasil analisis berdasarkan persamaan

$$
\text { lyzenga }
$$

Berdasarkan hasil pengamatan lapangan pada enam titik pengamatan diketahui kondisi terumbu karang sebagai berikut:

\begin{tabular}{ccccc}
\multicolumn{5}{c}{$\begin{array}{c}\text { Tabel 1. hasil pengamatan lapangan dan perbandingan dengan } \\
\text { hasil interpretasi citra dengan persamaan lyzenga }\end{array}$} \\
\hline No & Titik Pantau & $\begin{array}{c}\text { Kepadatan } \\
\text { Karang Hidup }\end{array}$ & $\begin{array}{c}\text { Kondisi Karang } \\
\text { (hasil survey) }\end{array}$ & $\begin{array}{c}\text { Kondisi } \\
\text { Karang } \\
\text { (hasil analisis) }\end{array}$ \\
\hline 1 & Titik Pantau A & $79 \%$ & Baik & Baik \\
2 & Titik Pantau B & 86 & Baik & Baik \\
3 & Titik Pantau C & 45 & Rusak & Baik \\
4 & Titik Pantau D & 47 & Rusak & Baik \\
5 & Titik Pantau E & 75 & Baik & Baik \\
6 & Titik Pantau F & 82 & Baik & Baik \\
7 & Titik Pantau G & Lamun & - & Baik \\
8 & Titik Pantau H & 92 & Baik & Baik \\
\hline
\end{tabular}

SPATIAL Wahana Komunikasi dan Informasi Geografi Vol. 13 No. 1 Maret 2015 
Berdasarkan hasil pengamatan lapangan diketahui bahwa dari 8 titik pengamatan terdapat 1 lokasi yang berbeda dengan hasil analisis citra. Pada citra menunjukan terumbu karang dengan kondisi buruk, namun dilapangan merupakan padang lamun dengan kepadatan rendah. Dan terdapat 2 lokasi pada citra didentifikasi sebagai terumbu karang dengan kondisi baik dimana jumlah karang hidup didentifikasi > $50 \%$, namun hasil pengamatan lapangan merupakan karang mati (kondisi rusak) dimana jumlah karang hidup < $50 \%$. Sedangkan titik pengamatan lainnya menunjukan hasil yang sesuai.

Persamaan lyzenga dikembangkan untuk landsat 7 ETM dengan menggunakan saluran 1,2 dan 4. Dalam kajian ini menggunakan landsat 8 dengan saluran 2,3 dan 5 yang memiliki kemiripan panjang gelombang 1,2 dan 4 pada landsat 7 walaupun tidak seluruhnya sama. Berikut adalah perbandingan panjang geolombang landsat 7 dan 8.

Tabel 2. Perbandingan Landsat 7 dan Landsat 8

\begin{tabular}{|c|c|c|c|}
\hline \multicolumn{4}{|c|}{ ETM+ and OLI/IIRS Spectral Bands } \\
\hline \multirow[t]{2}{*}{ L7 ETM+ Bands } & \multicolumn{2}{|l|}{ LDCM OLI/TIRS Band Requirements } & \multirow{4}{*}{$\begin{array}{l}\text { *Explanation of Differences } \\
\text { A. Coastal Band added at request of ocean color } \\
\text { investigators requiring higher resolution of coastal } \\
\text { waters relative to MODIS and SeaWiFS. }\end{array}$} \\
\hline & $30 \mathrm{~m}$, Coastal//Aerosol, $0.433-0.453 \mu \mathrm{m}\left({ }^{*} \mathrm{~A}\right)$ & Band 1 & \\
\hline Band $130 \mathrm{~m}$, Blue, $0.450-0.515 \mu \mathrm{m}$ & $30 \mathrm{~m}$, Blue, $0.450-0.515 \mu \mathrm{m}$ & Band 2 & \\
\hline Band $230 \mathrm{~m}$, Green, $0.525-0.605 \mu \mathrm{m}$ & $30 \mathrm{~m}$, Green, $0.525-0.600 \mu \mathrm{m}$ & Band 3 & \\
\hline Band $330 \mathrm{~m}$, Red,, $0.630-0.690 \mu \mathrm{m}$ & $30 \mathrm{~m}$, Red, $0.630-0.680 \mu \mathrm{m}$ ("B) & Band 4 & \multirow{3}{*}{$\begin{array}{l}\text { B. Bandwidth refinements made to avoid atmospheric } \\
\text { absorption features (enabled by the higher signal-to- } \\
\text { noise ratio inherent in push-broom architecture). }\end{array}$} \\
\hline Band $430 \mathrm{~m}$, Near- $-\mathrm{R}, 0.775-0.900 \mu \mathrm{m}$ & $30 \mathrm{~m}$, Nearl-1R, $0.845-0.885 \mu \mathrm{mm}$ ("B) & Band 5 & \\
\hline Band $530 \mathrm{~m}, \mathrm{SWIR}-1,1.550-1.750 \mu \mathrm{m}$ & 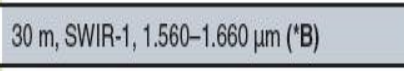 & Band 6 & \\
\hline Band $730 \mathrm{~m}, \mathrm{SWIR}-2,2.090-2.350 \mu \mathrm{m}$ & $30 \mathrm{~m}, \mathrm{SWIR}-2,2.100-2.300 \mu \mathrm{m}$ ("B) & Band 7 & \multirow{5}{*}{$\begin{array}{l}\text { C. Cirrus Band added to detect cirrus contamination in } \\
\text { other channels. } \\
\text { D. TIRS will acquire the data for these two thermal } \\
\text { bands. }\end{array}$} \\
\hline \multirow[t]{2}{*}{ Band $815 \mathrm{~m}$, Pan, $0.520-0.900 \mu \mathrm{m}$} & $15 \mathrm{~m}, \operatorname{Pan} 0.500-0.680 \mu \mathrm{m}$ ('B) & Band 8 & \\
\hline & $30 \mathrm{~m}$, Cirrus, $1.360-1.390 \mu \mathrm{m}$ ("C) & Band 9 & \\
\hline \multirow[t]{2}{*}{ Band $6 \quad 60 \mathrm{~m}, \mathrm{LWIR}, 10.00-12.50 \mu \mathrm{m}$} & 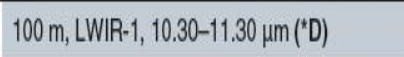 & Band 10 & \\
\hline & $100 \mathrm{~m}, \mathrm{LW} / \mathrm{R}-2,11.50-12.50 \mu \mathrm{m}$ ('D) & Band 11 & \\
\hline
\end{tabular}

Sumber : NASA. "Landsat Data Continuity Mission Brochure")

\section{Sebaran terumbu karang}

Topografi dasar perairan di pulau Sepanjang cenderung landai dengan kedalaman rataan terumbu karang dengan tingkat keragaman dan penutupan yang relative tinggi pada kedalaman 5-15 meter. Terdapat formasi berupa hamparan berbagai karang massif, sumasif, bercabang, karang lunak, hydrid, dan beberapa karang daun dalam populasi rapat dan luasan cukup besar. Dasar terdalam sekeliling hamparan terumbu karang dalam berpasir dengan lebih sedikit tutupan terumbu dan hidup dalam kelompok yang terpisah.

Berdasarkan hasil pengolahan data citra Landsat 8 dengan persamaan lyzenga dan hasil koreksi melalui pengamatan lapangan menunjukan bahwa Sebaran terumbu karang umumnya berada di bagian selatan Pulau Sepanjang, bebentuk memanjang seperti sabuk yang melingkari pulau di bagian selatan. Total luas terumbu karang di wilayah penelitian sebesar 1.025.014 ha dengan prosentase terumbu karang dengan kondisi baik mencapai $91,84 \%$. Adapun luas sebaran terumbu 
Tabel 3. Luas terumbu karang di perairan bagian selatan Pulau Sepanjang

\begin{tabular}{|c|c|c|c|}
\hline No & Kondisi Terumbu Karang & Luas $(\mathrm{Ha})$ & Luas (\%) \\
\hline 1 & Baik & 941.394 & 91.84 \\
\hline \multirow[t]{2}{*}{2} & Rusak & 83.620 & 8.16 \\
\hline & & 1.025 .014 & 100 \\
\hline
\end{tabular}

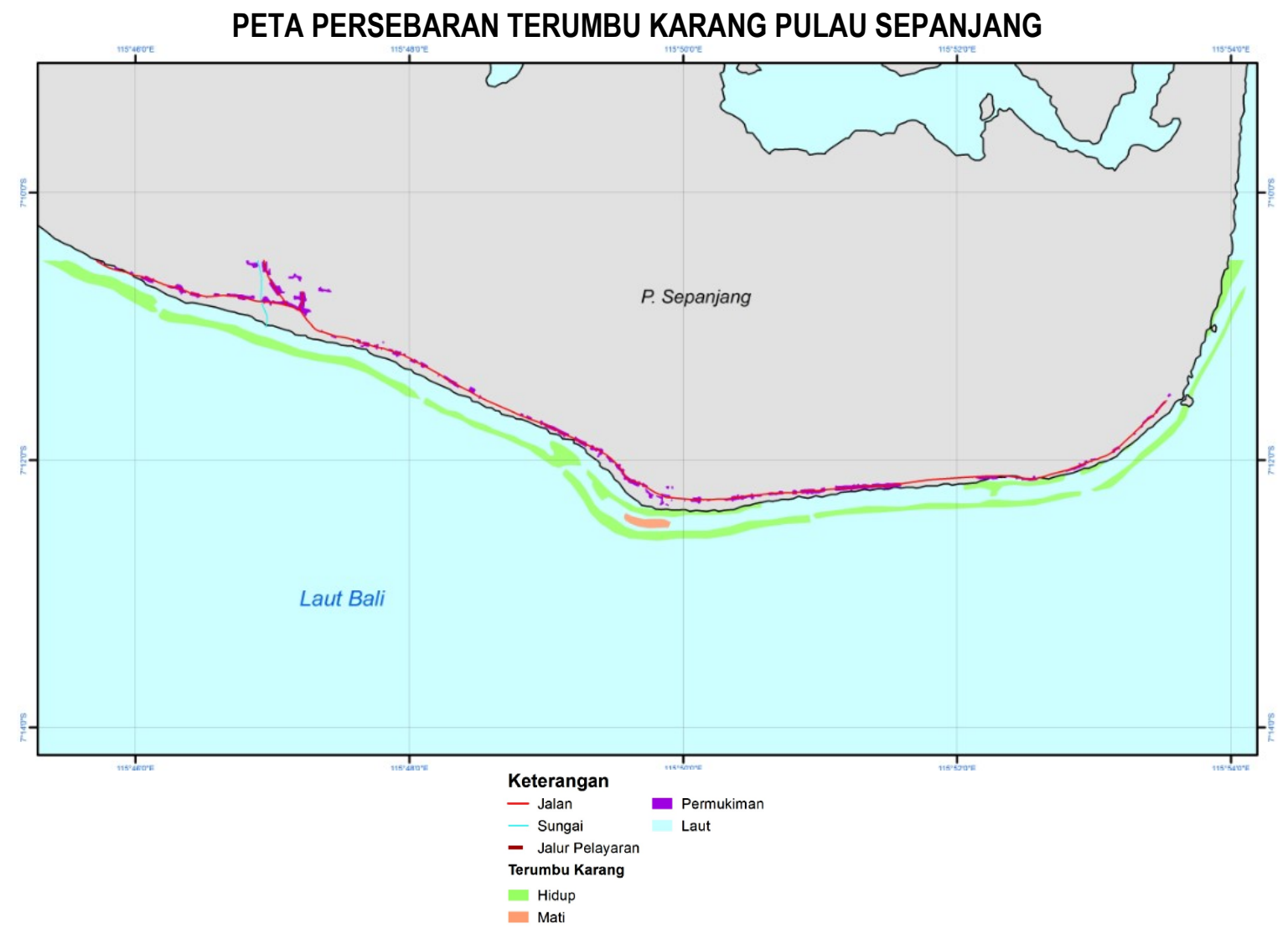

\section{KESIMPULAN}

1.Berdasarkan pengamatan lapangan, perbedaan antara hasil pengamatan lapangan dengan hasil analisis mencapai $37,5 \%$ perbedaan ini dijadikan sebagai dasar untuk melakukan koreksi pada citra untuk menghasilkan citra yang lebih tepat

2.Secara umum penggunaan persamaan/algoritma lyzenga pada landsat 8 bisa digunakan untuk mendeteksi kondisi umum terumbu karang khususnya untuk mendeteksi terumbu karang hidup dan mati, sebagai langkah awal untuk mengidentifikasi kualitas terumbu karang.

\section{DAFTAR PUSTAKA}

Bengen, D. G. 2002. Sinopsis Ekosistem dan Sumberdaya Alam Pesisir dan Laut serta Prinsip Pengelolaannya. Pusat Kajian Sumberdaya Pesisir dan Lautan Institut Pertanian Bogor. Bogor.

Dahuri R., Rais Y., Putra S.,G., Sitepu, M.J. 2001. Pengelolaan Sumber daya Wilayah Pesisir dan Lautan Secara Terpadu. PT. Pradnya Paramita, Jakarta.

Dahuri, R., Rais, J., Ginting, SP., dan Sitepu. 1996. Pengelolaan Sumberdaya 
Wilayah Pesisir dan Lautan Secara Terpadu. PT Pradnya Paramita. Jakarta.

Dahuri, R. 2000. Kebijakan dan Strategi Pengelolaan Terumbu Karang di Indonesia. Prosiding Seminar Internasional Penginderaan Jauh Dalam Pengembangan Ekonomi dan Pelestarian Lingkungan. Hotel Kartika Candra, Jakarta, 11-12 April 2000.

Dinas Kelautan dan Perikanan Kabupaten Jepara. 2008. Buku Saku Tahun 20062008. Jepara

Dutton, I.M., D.G. Bengen and J.J. Tulungen. 2001. The Challenges of Coral Reefs Management in Indonesia. In : Oceanographic Process of Coral Reefs : Physical and Biological Links in The Great Barrier Reefs. Ed. Eric Wolanski. CRC Press.

Darsono. 2007. Metode Riset Agribisnis. Surabaya. Program Studi Magister Manajemen Agribisnis Pasca Sarjana UPN "Veteran" Jawa Timur

Haeruman, H. 1986. Pedoman Pengelolaan dan Pengembangan Lingkungan Alam Wilayah Pesisir. Kantor Menteri Negara $\mathrm{KLH}$, Jakarta

Haeruman, H. 1987. Flora dan Fauna. Pengelolaan Wilayah Pesisir. Proyek Penelitian Pengembangan Sumberdaya Laut dan Pencemaran Laut. Kantor Menteri Negara KLH, Jakarta.

Kantor Menteri Negara Lingkungan Hidup. 1990. Kualitas Lingkungan di Indonesia. PT.Indermasa: Jakarta.

Komar,P.D. 1983. Handbook of Coastal Processes and Erosion.CRC Pres, Inc.Boca Raton, Florida.
Lillesand, T.M, R.W. Kiefer and J.W.Chipman. 2004. Remote Sensing and Image Interpretation(5ed). John Wiley and Sons :New York.

Moosa, M. K., B. Hasyim, dan G. Winarso. 2000. Pemetaan Terumbu Karang Menggunakan Data Inderaja dan SIG untuk Mendukung COREMAP.

Prosiding Seminar Internasional Penginderaan Jauh Dalam Pengembangan Ekonomi dan Pelestarian Lingkungan. Hotel Kartika Candra, Jakarta, 11-12 April 2000.

Nontji.A. 1993. Laut Nusantara.Djambatan.Jakarta Nybakken, J.W. 1988. Biologi Laut: Suatu Pendekatan Ekologis. PT Gramedia. Jakarta.

Ongkosongo, O. S. R. 1983. Terumbu Karang di Indonesia: Sumbedaya, Permasalahan dan Pengelolaannya. LON-LIPI. Jakarta.

Purwadhi, S. H. 2001. Interpretasi Citra Dijital. PT Gramedia Widiasarana Indonesia. Jakarta.

Sukarno, R. 1993. Mengenal Ekosistem Terumbu Karang dalam Materi Kursus Pelatihan Metodologi Penelitian Penentuan Kondisi Terumbu Karang. P3O-LIPI. Jakarta.

Sutomo, AB. 1984. The final report of the marine investigation of the Paiton waters, East Java. The report submitted to PT Ciria Jasa. National Institute of Oceanology - LIPI: 207 pp

Wening, D. 2005. Kajian Kerusakan Terumbu Karang akibat Limbah PLTU Suralaya di Banten dengan Memanfaatkan Teknologi Penginderaan Jauh dan Sistem Informasi Geografis.Tesis. Universitas Gadjah Mada. Yogjakarta.

http://www.coremap.or.id/tentang_karang/ diakses pada tanggal 27 januari 2015 pukul 14.30

https://tnrawku.wordpress.com/2013/06/12/landsat -8-spesifikasi-keungulan-dan-peluangpemanfaatan-bidang-kehutanan/ diakses pada 27 januari 2015 